\title{
Penerapan Fair Trial Dalam Menentukan Usia Anak, Tinjauan Terhadap Sistem Peradilan Pidana
}

\author{
Dini Eka Wati \\ Email : dini.eka@ui.ac.id \\ Magister Hukum, Universitas Indonesia
}

\begin{abstract}
The aim of this study is to find out the application of fair trial principle in the criminal justice system and legal protection that should be given to children who become the victims of unfair trial in the criminal justice. This study was carried out by examining statutory regulations both related to fomal criminal law and material criminal law. The study used in this paper was normative juridical conducted by examining and reviewing library materials or secondary data by referring to legal norms contained in statutory regulations, court rulings, and legal norms that exist in society with a qualitative method and descriptive prescriptive approach. The results of this study showed that the application of fair trial principle in Indonesia, had not been carried out optimally. It was proven by there were still many cases happened, as well as the legal vacuum to provide protection for children who were the victims of unfair trial in criminal justice.
\end{abstract}

\section{Keywords: Fair Trial, Criminal Justice System, Victim}

Penelitian ini bertujuan untuk mengetahui penerapan prinsip fair trial dalam sistem peradilan pidana serta perlindungan hukum yang seharusnya diberikan terhadap anak yang menjadi korban unfair trial dalam peradilan pidana. Penelitian dilakukan dengan mengkaji peraturan perundang-undangan baik yang berkaitan dengan hukum pidana formil maupun hukum pidana materiil. Penelitian yang digunakan dalam penulisan ini adalah yuridis normatif yang dilakukan dengan cara meneliti dan mengkaji data sekunder berupa norma-norma hukum yang terdapat dalam peraturan perundang-undangan, putusan pengadilan, dan norma hukum yang ada dalam masyarakat dengan metode kualitiatif pendekatan deskriptif preskriptif.Hasil penelitian menunjukkan bahwa penerapan prinsip fair trial di Indonesia belum dilakukan secara optimal, terlihat dari masih banyaknya kasus yang terjadi, serta masih terjadinya kekosongan hukum mengenai perlindungan terhadap anak yang menjadi korban unfair trial dalam peradilan pidana.

\section{Kata Kunci: Fair Trial, Sistem Peradilan Pidana, Korban}

\section{PENDAHULUAN}

Beberapa tahun belakangan, banyak diberitakan mengenai peradilan pidana yang dinilai masih rentan dengan adanya ketidakadilan. Setidaknya ungkapan pedang tajam ke atas dan tumpul ke bawah yang dimiliki oleh Dewi Keadilan merupakan gambaran nyata dari sistem peradilan pidana di Indonesia. Masyarakat menilai bahwa peradilan pidana yang saat ini ada menunjukkan lemahnya kinerja aparat penegak hukum baik dalam tahap penyelidikan sampai dengan pemasyarakatan. Baru-baru ini terjadi adalah seorang Ibu 3 (tiga) anak yang dijatuhi pidana penjara 7 (tujuh) hari karena karena mengambil tandan buah sawit milik PTPN V yang 
nilainya tidak lebih dari Rp. 76.500,00 (tujuh puluh enam ribu lima ratus rupiah). ${ }^{[1]}$ Apabila menilik ke belakang, masyarakat juga tidak akan lupa dengan kasus seorang nenek berusia 55 tahun yang harus diadili karena mengambil 3 (tiga) buah kakao dijatuhi hukuman 1 (satu) bulan 5 (lima) hari. ${ }^{[2]}$ Tidak dapat dipungkiri, di Indonesia seberapa kecilpun nilai barang yang dicuri, pencurian tetaplah dianggap pencurian.

Kekeliruan yang muncul kemudian tidak dapat dilepaskan dari peradilan pidana yang tidak berhasil menerapkan prinsip fair trial. Padahal, penerapan prinsip fair trial merupakan perwujudan terhadap perlindungan hak asasi manusia yang mendasari bekerjanya sistem peradilan pidana terpadu (integrated criminal justice system). Hal ini terlihat dari berbagai kasus yang menjadikan anak sebagai korban atas ketidakadilan sistem peradilan pidana, misalnya terhadap seorang anak bernama Yusman Telaumbanua yang dijatuhi hukuman pidana mati atas kasus pembunuhan karena kekeliruan aparat penegak hukum dalam menerapkan hukum, di mana usia Yusman dalam berkas perkara diubah menjadi 19 (sembilan belas) tahun agar dapat dituntut sebagaimana orang dewasa. Padahal seharusnya Yusman tidak dapat dijatuhi pidana mati karena masih berusia anak sebagaimana diatur dalam UU No. 3 Tahun 1997 Tentang Pengadilan Anak, yang kemudian diubah dengan UU No. 11 Tahun 2012 Tentang Sistem Peradilan Pidana Anak. Kasus Yusman kemudian berkembang dengan adanya penemuan bukti baru atau novum yang diperoleh dari hasil lab gigi yang menunjukkan usia asli Yusman adalah 15-16 tahun pada saat kejadian. ${ }^{[3]}$

Kekeliruan aparat penegak hukum dalam menerapkan hukum khususnya usia anak tidak selesai pada kasus yang menimpa Yusman Telaumbanua saja. Pada tahun 2019, seorang anak berinisial IH yang terlibat dalam gerakan melawan rasisme didakwa atas tindak pidana perusakan. Majelis Hakim Pengadilan Negeri Jayapura melalui putusan sela akhirnya mengabulkan eksepsi Penasihat Hukum karena berdasarkan pemeriksaan gigi, IH belum genap berusia 18 (delapan belas) tahun pada saat kejadian. ${ }^{[4]}$ Tidak berhenti di situ, seorang anak yang berasal dari Papua bernama Mispo Gwijangge didakwa karena keterlibatannya dalam kelompok kriminal bersenjata dan melakukan pembunuhan dengan ancaman pidana maksimal pidana mati. Terdapat kejanggalan di antaranya adalah ketidakjelasan usia Mispo Gwijangge yang hanya didasarkan pada surat keterangan domisili di luar domisili.

Adanya ketidakjelasan usia tersebut, dilakukan proses pemeriksaan terhadap tulang dan gigi yang mana menujukkan bahwa usia Mispo Gwijangge adalah 15,5 tahun pada saat kejadian. ${ }^{[5]}$ Namun dalam putusan sela yang dijatuhkan oleh Majelis Hakim Pengadilan Negeri (PN) Jakarta

1 CNN. Survei LSI Kepercayaan Publik Terhadap POLRI Paling Merosot. https://www.cnnindonesia.com/ nasional/20191113181236-20-448092/survei-lsi-kepercayaan-publik-terhadap-polri-paling-merosot diakses pada tanggal 04 Juni 2020.

2 Detik. Mencuri 3 Buah Kakao Nenek Minah Dihukum 1 Bulan 15 Hari. https://news.detik.com/berita/d-1244955/ mencuri-3-buah-kakao-nenek-minah-dihukum-1-bulan-15-hari diakses pada tanggal 07 Juni 2020.

${ }^{3}$ Kompas, Kisah Yusman Mantan Terpidana Mati Dibawah Umur Yang Mengaku Kena Rekayasa. https://nasional.kompas. $\mathrm{com} / \mathrm{read} / 2017 / 08 / 23 / 12060601 /$ kisahyusmanmantanterpidanamatidibawahumuryangmengakukenarekayasa?page=all diakses pada tanggal 08 Juni 2020.

4 Makassar Terkini. Tim Advokat Untuk Orang Asli Papua Terdakwa IH Dibebaskan Dari Tahanan. https://makassar. terkini.id/tim-advokat-untuk-orang-asli-papua-terdakwa-ih-dibebaskan-dari-tahanan/diakses pada tanggal 07 Juni 2020

5 Voa Indonesia, Terdakwa Hukuman Mati Kasus Istaka Karya Papua Diduga Masih Anak. https://www.voaindonesia. com/a/terdakwa-hukuman-mati-kasus-istaka-karya-papua-diduga-masih-anak/5306384.html diakses pada tanggal 08 Juni 2020. 
Pusat, Majelis Hakim menerima eksepsi dari Penasihat Hukum Mispo Gwijangge, yang menyatakan dakwaan Jaksa Penuntut Umum tidak dapat diterima, dan Mispo Gwijangge di keluarkan dari tahanan. Dengan demikian, kasus yang menimpa anak dibawah umur sebagaimana telah diuraikan di atas menunjukkan bahwa keadilan dalam sistem peradilan pidana di Indonesia masih jauh dari yang diharapkan, terlebih anak-anak sebagai generasi penerus bangsa dalam posisinya yang rentan seharusnya memperoleh perlindungan.

Sebagai generasi penerus bangsa, anak setidaknya telah memperoleh perlindungan sejak berada dalam kandungan. Kewajiban melindungi anak tidak lain bertujuan agar anak tidak menjadi korban dari perbuatan orang lain, baik perbuatan yang dilakukan secara langsung maupun tidak langsung. ${ }^{[6]}$ Anak yang kurang mampu secara fisik, mental, dan sosial, membutuhkan perhatian dan bimbingan khusus termasuk perlindungan hukum. ${ }^{[7]}$ Perlindungan hukum berarti memberikan pengayoman terhadap hak asasi manusia (HAM) yang dirugikan orang lain dan perlindungan tersebut diberikan kepada masyarakat agar dapat menikmati semua hak-hak yang diberikanolehhukum. ${ }^{[8]}$

Dengan kata lain perlindungan hukum sebagai suatu gambaran dari fungsi hukum, yaitu konsep dimana hukum dapat memberikan suatu keadilan, kepastian, dan kemanfaatan. Perlindungan hukum terhadap anak salah satunya diwujudkan dalam peradilan pidana anak. Dalam peradilan pidana anak, keadilan dipengaruhi oleh tindakan dari para penegak hukum, hal ini menunjukkan bahwa perlindungan anak erat kaitannya dengan keadilan. ${ }^{[9]}$ Apabila dihubungkan dengan perlindungan anak, maka dalam keadilan yang baik tercermin perlindungan anak, dan perlindungan anak yang baik mencerminkan keadilan, yaitu diwujudkan dengan terpenuhinya hak-hakanak. ${ }^{[10]}$

Negara Indonesia menjamin seluruh individu pencari keadilan untuk memperoleh kepastian hukum, sebagaimana yang disebutkan dalam Pasal 27 ayat (1) Undang-Undang Dasar 1945: "Segala warga negara bersamaan kedudukannya di dalam hukum dan pemerintahan, wajib menjunjung tinggi hukum dan pemerintahan itu dengan tidak ada kecualinya. ${ }^{[11]}$ Lebih lanjut Pasal 28 D ayat (1) Undang-Undang Dasar 1945 juga menyebutkan bahwa: "Setiap orang berhak atas pengakuan, jaminan, perlindungan, dan kepastian hukum yang adil serta perlakuan yang sama di hadapan hukum". Selain itu, dengan diratifikasinya Convention on The Rights of The Child atau Konvensi Hak-hak Anak melalui Keputusan Presiden No. 36 Tahun 1990, maka negara Indonesia berkewajiban untuk mengimplementasikan konvensi tersebut. Perlindungan hukum terhadap anak dalam sistem peradilan pidana dikhususkan kepada anak yang berhadapan dengan hukum, di antaranya adalah anak yang berkonflik dengan hukum, anak yang menjadi korban tindak pidana, dan anak yang menjadi saksi tindak pidana. ${ }^{[12]}$

6 Arif Gosita, 2004, Masalah Perlindungan Anak, Bhuana Ilmu Populer, Jakarta 2004, hal.35

${ }^{7}$ Maidin Gultom, 2014, Perlindungan Hukum Terhadap Anak dalam Sistem Peradilan Pidana Anak di Indonesia, Refika Aditama, Jakarta, hal.77

${ }^{8}$ Wagiati Soetedjo, 2011, Hukum Pidana Anak, Refika Aditama, Bandung, hal.76

${ }^{9}$ Ibid., hal.35

${ }^{10}$ Ibid., hal.36

${ }^{11}$ Undang-Undang Dasar 1945 Amandemen IV, Lembaran Negara No.14 Tahun 2006.

12 Undang-Undang Sistem Peradilan Pidana Anak, UU No. 11 Tahun 2012, Lembaran Negara No. 153 Tahun 2012, Tambahan Lembaran Negara No. 5332. 
Dari latar belakang tersebut di atas, dapat dirumuskan 2 (dua) permasalahan sebagai berikut : Pertama, bagaimana penerapan fair trial dalam sistem peradilan pidana. Kedua, bagaimana perlindungan yang seharusnya diberikan terhadap anak yang menjadi korban unfair trial.

\section{METODE PENELITIAN}

Penelitian yang digunakan dalam penulisan ini adalah yuridis normatif yang dilakukan dengan cara meneliti dan mengkaji data sekunder berupa norma-norma hukum yang terdapat dalam peraturan perundang-undangan, putusan pengadilan, dan norma hukum yang ada dalam masyarakat. Adapun pendekatan yang digunakan penulis dalam penulisan ini adalah pendekatan peraturan perundang-undangan (statute approach), pendekatan kasus (the case approach), dan pendekatan konseptual (conceptual approach).

\section{PEMBAHASAN}

\section{A. Penerapan Fair Trial Dalam Sistem Peradilan Pidana}

Fair trial menurut kamus hukum diartikan sebagai persidangan pengadilan yang dilakukan sesuai prosedur. Salah satu unsur penting adalah ketidakberpihakan. ${ }^{[13]}$ Ketidakberpihakan dapat diartikan sebagai peradilan yang berimbang, yang lebih tepat dengan asas persamaan di hadapan hukum atau equality before the law. ${ }^{[14]}$ Sementara itu, Ranu Handoko menyebutkan bahwa fair trial merupakan proses peradilan yang jujur sejak awal sampai akhir. ${ }^{[15]}$ Dalam sistem peradilan pidana, dapat dimulai dari tahap penyelidikan sampai dengan pemasyarakatan.

Fair trial merupakan perwujudan dari perlindungan terhadap hak asasi manusia yang mendasari bekerjanya sistem peradilan pidana. Dalam sistem peradilan pidana, tersangka atau terdakwa dipandang sebagai subjek yang memiliki hak dan kewajiban untuk menuntut ganti rugi atau rehabilitasi apabila petugas salah tangkap, salah tahan, salah tuntut, dan salah hukum. Jaminan perlindungan terhadap hak dan kewajiban tersebut merupakan perwujudan Indonesia sebagai negara hukum (rechtstaat) sebagaimana banyak dianut oleh negara-negara Eropa Kontinental yang bertumpu pada sistem civil law.

John Friedrich Staal sebagaimana yang dikutip oleh Prof. Jimly Assiddiqie menyebutkan, setidaknya terdapat 4 (empat) unsur dalam negara hukum, yaitu adanya pengakuan hak asasi manusia, adanya pembatasan kekuasaan, adanya pemerintahan yang berdasarkan pada undangundang, dan adanya pengadilan administrasi negara. ${ }^{[16]}$ Padmo Wahyono menyebutkan bahwa negara hukum harus berjalan dalam suatu sistem yang saling berhubungan, yang dilakukan dengan cara menghormati dan melindungi hak asasi manusia, mekanisme kelembagaan negara yang demokratis, tertib hukum, dan kekuasaan kehakiman yang bebas.

\footnotetext{
${ }^{13}$ Fauzan dan Baharuddin Siagian, 2017, Kamus Hukum dan Yurisprudensi Prena Media, Jakarta, hal. 261

14 O.C.Kaligis, 2006, Perlindungan Hukum atas Hak Asasi Tersangka Terdakwa dan Terpidana, Alumni, Bandung, hal.105

${ }_{15}$ Ranu Handoko, 1996, Terminologi Hukum, Sinar Grafika, Jakarta, hal.26

16 Jimly Asshiddiqie, 2007, Pokok-Pokok Hukum Tata Negara Indonesia Pasca Reformasi, Bhuana Ilmu Populer, Jakarta,
} hal.301 
Dengan demikian, prinsip dasar dari negara hukum adalah adanya jaminan perlindungan dan penghormatan terhadap hak asasi manusia yang secara jelas dan tegas diatur secara khusus dalam Undang-Undang Dasar pada Bab XA yang terdiri dari Pasal 28A sampai dengan 28J. Adapun fair trial secara eksplisit diatur dalam Pasal 28D, 28G ayat (1), 28G (2), 28I ayat (2), dan 28I ayat (4) dengan ketentuan sebagai berikut :

Pertama, dalam Pasal 28D hak atas pengakuan, jaminan, perlindungan, dan kepastian hukum yang adil serta perlakuan yang sama di hadapan hukum. Kedua, Pasal 28G ayat (1) hak atas rasa aman dan perlindungan dari ancaman ketakutan untuk berbuat atau tidak berbuat sesuatu yang merupakan hak asasi. Ketiga, Pasal 28G ayat (2) hak untuk bebas dari penyiksaan atau perlakuan yang merendahkan derajat martabat manusia. Keempat, Pasal 28I ayat (2) hak untuk bebas dan memperoleh perlindungan dari perlakuan yang bersifat bersifat diskriminatif. Kelima, hak untuk memperoleh perlindungan, penegakan dan pemenuhan hak asasi manusia oleh negara.

Prinsip fair trial sebagaimana yang secara jelas dan tegas diatur dalam UUD 1945 tersebut kemudian diwujudkan dalam bekerjanya sistem peradilan pidana. Sistem peradilan pidana terdiri dari berbagai sub sistem yang mana masing-masing sub sistem tersebut memiliki fungsi yang berbeda-beda namun saling berhubungan. Mardjono Reksodiputro memberikan pembatasan terhadap sistem peradilan pidana sebagai suatu sistem yang digunakan untuk menanggulangi kejahatan yang terdiri dari lembaga kepolisian, kejaksaan, pengadilan, dan pemasyarakatan. ${ }^{[17]}$ Lebih lanjut dijelaskan bahwa, sebagai suatu sistem setidaknya sistem peradilan pidana bertujuan untuk :[18]

a. Mencegah masyarakat menjadi korban kejahatan;

b. Menyelesaikan kasus kejahatan yang terjadi sehingga masyarakat puas bahwa keadilan telah ditegakkan dan yang bersalah dipidana;

c. Mengusahakan agar mereka yang pernah melakukan kejahatan tidak mengulangi lagi kejahatannya

Dari ketiga tujuan tersebut di atas, kepastian hukum tidak semata-mata menjadi tolok ukur keberhasilan sistem peradilan pidana, namun juga terdapat hal yang tidak kalah pentingnya yaitu keadilan dan kemanfaatan. Sistem peradilan pidana yang diterapkan di Indonesia didasarkan pada berlakunya Kitab Undang-Undang Hukum Acara Pidana (KUHAP) yang menggantikan HIR, sehingga sistem peradilan pidana yang diterapkan mulaibergeserkepada model adversary system. ${ }^{[19]}$ Adversary system merupakan model yang banyak berkembang di negara-negara common law, yang memiliki karakteristik adanya perlindungan terhadap hak asasi tersangka atau terdakwa yang berlandaskan pada due process of law. ${ }^{[20]}$

Adapun tujuan utama dari adversary system adalah untuk melindungi orang yang tidak bersalah dan menuntut orang yang bersalah dengan proses penyelidikan secara formal dan

17 Mardjono Reksodiputro, 2009, Sistem Peradilan Pidana Indonesia (Melihat Kepada Kejahatan Dan Penegakan Hukum Dalam Batas-Batas Toleransi, Fakultas Hukum Unversitas Indonesia, Jakarta, hal.1

${ }^{18}$ Ibid., hal.3

19 Romli Atmasasmita, 1996, Sistem Peradilan Pidana Perspektif Eksistensialisme dan Abolisionisme, Bina Cipta, Bandung, hal. 20

${ }^{20}$ Op.cit., hal. 108. 
penemuan fakta secara objektif di hadapan persidangan. Penilaian terhadap dakwaan penuntut umum dilakukan setelah terdakwa memperoleh kesempatan sepenuhnya mengajukan fakta yang membantah atau menolak dakwaan yang diajukan kepadanya. ${ }^{[21]}$ Dengan mulai bergesernya sistem peradilan pidana kepada model adversary system, maka seharusnya para aparat penegak hukum dapat menekan terjadinya unfair trial dalam sistem peradilan pidana, namun yang terjadi justru sebaliknya.

Menilik pada kasus yang telah disebutkan di atas, perlu diuraikan bagaimana sub sistem peradilan pidana yaitu penyelidikan dan penyidikan dapat berkerja sebagaimana diatur dalam KUHAP. Pertama, dimulai dari tahap penyelidikan. Penyelidikan menurut Pasal 1 angka 5 KUHAP merupakan serangkaian tindakan penyelidik untuk mencari dan menemukan suatu peristiwa yang diduga sebagai tindak pidana guna menentukan dapat atau tidaknya dilakukan penyidikan menurut cara yang diatur dalam undang-undang ini. ${ }^{[22]}$ Polisi sebagai aparat penegak hukum yang bertugas untuk melakukan penyelidikan memiliki peran yang penting dalam menemukan dan menentukan apakah suatu peristiwa yang terjadi merupakan tindak pidana atau sebaliknya.

Kedua, penyidikan. Menurut Pasal 1 angka 2 KUHAP, penyidikan merupakan serangkaian tindakan penyidik dalam hal menurut cara yang diatur dalam undang-undang ini untuk mencari serta mengumpulkan bukti yang dengan bukti itu membuat terang tentang tindak pidana yang terjadi dan guna menemukan tersangkanya. Penyidikan dilakukan oleh polisi, dan juga pejabat pegawai negeri sipil tertentu yang diberi wewenang khusus oleh undang-undang untuk melakukan penyidikan. Dalam penegakan hukum pidana, proses penyidikan memainkan peran yang sangat penting. Di sisi lain untuk melaksanakan penegakan hukum pidana, di sisi lain juga melindundungi hak-hak asasi manusia yang dibatasi karena pelaksanaannya.

Hal yang menjadi perhatian utama dalam ketiga kasus tersebut di atas adalah adanya kekeliruan dalam menentukan usia orang. Hal ini tentu saja akan menjadi fatal apalagi kekeliruan tersebut berkaitan penjatuhan pidana. Dalam kasus Yusman Telaumbanua dan Mispo Gwijangge misalnya yang diancam dengan pidana mati, padahal di dalam Pasal 3 huruf e Undang-Undang Sistem Peradilan Pidana Anak disebutkan bahwa anak yang melakukan suatu tindak pidana tidak dijatuhi pidana mati atau pidana seumur hidup. UU No. 11 Tahun 2012 diundangkan atas dasar pertimbangan sebagai berikut :[23]

a. Anak merupakan amanah dan karunia Tuhan Yang Maha Esa yang memiliki harkat dan martabat sebagai manusia seutuhnya;

b. Untuk menjaga harkat dan martabatnya, anak berhak mendapatkan perlindungan khusus, terutama perlindungan hukum dalam sistem peradilan;

c. Indonesia sebagai Negara Pihak dalam Konvensi Hak-Hak Anak (Convention on the Rights of the (Child) yang mengatur prinsip perlindungan hukum terhadap anak mempunyai kewajiban untuk memberikan perlindungan khusus terhadap anak yang berhadapan dengan hukum;

\footnotetext{
${ }^{21}$ Ibid

${ }^{22}$ Undang-Undang No. 8 Tahun 1981 Tentang Kitab Undang-Undang Hukum Acara Pidana, Lembaran Negara Republik Indonesia No.76 Tahun 1981, Tambahan Lembaran Negara Republik Indonesia No.3209.

${ }^{23}$ Konsideran Undang-Undang No. 11 Tahun 2012 Tentang Sistem Peradilan Pidana Anak
} 
d. UU No. 3 Tahun 1997 tentang Pengadilan Anak sudah tidak sesuailagi dengan perkembangan dan kebutuhan hukum masyarakat karena belum secara komprehensif memberikan perlindungan kepada anak yang berhadapan dengan hukum sehingga perlu diganti dengan undang-undang baru.

Walaupun Indonesia telah memiliki Undang-Undang No. 3 Tahun 1997 tentang Pengadilan Anak, dan peraturan perundang-unrangan lainnya, dalam kenyataannya peraturan yang ada belum memenuhi prinsip-prinsip dasar Konvensi Hak-Hak Anak (KHA) sebagaimana yang telah diratifikasi berdasarkan Keputusan Presiden No. 36 Tahun 1990 Tentang Pengesahan Konvensi Hak-Hak Anak (KHA). Adapun prinsip-prinsip dasar KHA tersebut antara lain :

1. Non diskriminasi (non discrimination) semua hak yang terdapat dalam KHA harus diberlakukan kepada setiap anak tanpa kecuali.

2. Kepentingan terbaik bagi anak (the best interest of the child) segala tindakan yang dilakukan oleh pemerintah, masyarakat, yang menyangkut anak, harus mengutamakan kepentingan terbaik bagi anak

3. Hak untuk hidup, kelangsungan hidup, dan tumbuh kembang (survival and development) merupakan hak asasi yang paling mendasar bagi anak yang harus dilindungi oleh semua pihak.

4. Penghargaan terhadap pendapat anak (respect for the views of child) penghormatan terhadap hak-hak anak untuk berpartisipasi dan menyatakan pendapatnya dalam pengambilan keputusan yang berpengaruh terhadap kehidupannya.

Selanjutnya, dalam melakukan penyidikan, penyidik harus memperhatikan hak-hak yang dimiliki oleh seseorang, tanpa menggunakan ancaman atau kekerasan. Sebagai bentuk perlindungan terhadap hak-hak yang dimiliki oleh seseorang dalam tahap penyidikan, Pasal 8 ayat (1) Undang-Undang No. 48 Tahun 2009 Tentang Kekuasaan Kehakiman menyebutkan bahwa :[24]

"Setiap orang yang disangka, ditangkap, ditahan, dituntut, dan atau dihadapkan di depan pengadilan wajib dianggap tidak bersalah sebelum ada keputusan pengadilan yang menyatakan kesalahanya dan telah memperoleh kekuatan hukum tetap."

Jaminan perlindungan terhadap hak-hak seseorang dikenal dengan asas praduga tidak bersalah (presumption of innocence). Dalam menentukan orang tersebut bersalah atau tidak, ditentukan oleh pengadilan yang nantinya memberikan kesempatan kepada seseorang tersebut untuk memela dirinya sendiri, dengan demikian orang tersebut harus diperlakukan sebagaimana orang yang tidak bersalah.

Dalam kasus Yusman Telaumanua mengaku bahwa selama proses pemeriksaan di kepolisian tidak didampingi oleh penasihat hukum. Yusman juga tidak dapat berbahasa Indonesia dengan baik, sehingga bahasa yang digunakan adalah bahasa daerah, Yusman juga mengaku tidak bisa membaca atau menulis. Selama di tahanan, Yusman juga kerap kali ditendang dan dipukuli oleh polisi. ${ }^{[25]}$ Mispo Gwijangge juga mengaku bahwa pada saat pemeriksaan, tidak didampingi oleh keluarga maupun penasihat hukum, tidak dibantu oleh penerjemah saat diambil keterangannya. ${ }^{[26]}$

${ }^{24}$ Undang-Undang No. 48 Tahun 2009, Lembaran Negara Republik Indonesia No. 157 Tahun 2009, Tambahan Lembaran Negara Republik Indonesia No. 5076

${ }^{25}$ Kompas, Kisah Yusman Mantan Terpidana Mati Dibawah Umur Yang Mengaku Kena Rekayasa. https://nasional.kompas. com/read/2017/08/23/12060601/kisahyusmanmantanterpidanamatidibawahumuryangmengakukenarekayasa?page=all diakses pada tanggal 08 Juni 2020.

${ }^{26}$ Voa Indonesia, Terdakwa Hukuman Mati Kasus Istaka Karya Papua Diduga Masih Anak. https://www.voaindonesia. $\left.\begin{array}{r|l}r \mid 7 \\ \hline \leftarrow 7\end{array}\right]$ 
Bahkan saat pembuatan berita acara pemeriksaan (BAP), Mispo Gwijangge juga mengalami ancaman dan kekerasan. ${ }^{[27]}$ Berdasarkan hasil temuan Institue Criminal of Justice Reform (ICJR), terdapat karakter kasus dan pelaku tertentu di mana tindakan penyiksaan dapat terjadi. Apabila dilihat dari sisi pelaku, masyarakat miskin dan tidak mengerti hukum menjadi korban penyiksaan. Sedangkan dari sisi tindak pidana yang dilakukan, penyiksaan terjadi terhadap kasus-kasus tindak pidana biasa yang umumnya melibatkan masyarakat kecil.

Penyiksaan umumnya dilakukan pada saat melakukan penangkapan, penggeledahan, pengambilan keterangan untuk dimasukkan ke dalam BAP, dan penahanan, sebagaimana dikatakan oleh Barker bahwa penyiksaan terjadi karena seorang polisi menggunakan kekuatan lebih dari yang dibutuhkan atau penggunaan kekuatan fisik yang berlebihan terhadap orang lain tanpa alasan. ${ }^{[28]}$ Lebih lanjut, ketiganya tidak memperoleh bantuan hukum atau penasihat hukum sejak awal pemeriksaan. Padahal diperolehnya bantuan hukum bukan semata-mata digantungkan kepada pelaku, tetapi dengan sendirinya sudah menjadi kewajiban bagi penyidik atau aparat penegak hukum pada semua tahap pemeriksaan untuk memberikan hak atas bantuan hukum tersebut.

Dengan demikian, dari tahap penyelidikan sampai penyidikan yang telah dipaparkan di atas, diperoleh kesimpulan bahwa fakta hukum yang ditemukan oleh penyidik bukanlah suatu kebenaran materiil sebagaimana yang dikehendaki dalam fair trial. Kekeliruan yang dilakukan sejak dalam tahap penyelidikan dan penyidikan dijadikan dasar bagi jaksa penuntut umum untuk membuat dakwaan. Hal tersebut kemudian menjadi salah satu faktor penyebab runtuhnya kepercayaan masyarakat terhadap praktik peradilan pidana yang ada di Indonesia.

\section{B. Perlindungan Terhadap Anak Korban Unfair Trial}

Anak yang menjadi korban unfair trial tersebut tidak hanya berdasar pada kekeliruan aparat penegak hukum dalam menerapkan hukum terhadap anak. Anak yang seharusnya diperiksa dan diadili dengan menggunakan peradilan pidana anak mau tidak mau harus mengalami kekerasan dan ancaman dalam penangkapan, dan pahitnya lagi harus menghadapi pidana mati. Selama ini, apabila terdapat kekeliruan dalam tugasnya sebagai penegak hukum, penyidik hanya melakukan pembebasan disertai permohonan maaf kepada korban. Padahal bisa jadi korban merupakan tulang punggung keluarga yang kehilangan pekerjaannya, atau bahkan merupakan anak yang kehilangan masa depannya

Adapun yang dimaksud dengan korban adalah orang yang mederita baik jasmaniah maupun rohaniah karena perbuatan orang lain yang bertentangan dengan kepentingan diri sendiri atau orang lain yang mencari pemenuhan kepentingan diri sendiri atau orang lain yang bertentangan

com/a/terdakwa-hukuman-mati-kasus-istaka-karya-papua-diduga-masih-anak/5306384.html diakses pada tanggal 08 Juni 2020.

${ }^{27}$ Tribun. Begini Kisah Mispo Gwijangge Bocah 14 Tahun Yang Dituduh Bunuh 17 Karyawan PT Istaka Karya Di Ndug. https://tribun-arafura.com/2020/02/04/begini-kisah-mispo-gwijangge-bocah-14-tahun-yang-dituduh-bunuh-17-karyawan-pt-istakakarya-di-nduga/ diakses pada tanggal 03 Juni 2020.

${ }^{28}$ Agus Raharjo dan Angkasa, "Profesionalisme Polisi dalam Penegakan Hukum", Jurnal Dinamika Hukum, Vol. 11 No.3, September 2011, hal. 392 
dengan kepentingan hak asasi yang menderita. ${ }^{[29]}$ Lebih lanjut Stanciu mengartikan korban dalam arti luas sebagai orang yang menderita akibat adanya ketidakadilan. ${ }^{[30]}$ Setidaknya terdapat 6 (enam) prinsip yang harus dipenuhi oleh negara dalam rangka merumuskan kebijakan untuk melindungi dan memenuhi hak-hak korban, sebagai berikut : ${ }^{[31]}$

Pertama, pemulihan dapat dituntut secara individual maupun kolektif. Kedua, negara berkewajiban menerapkan langkah-langkah khusus yang memungkinkan dilakukannya langkahlangkah pemulihan yang efektif secara penuh. Pemulihan harus seimbang dengan beratnya pelanggaran dan kerusakan-kerusakan yang diakibatkannya, yang mencakup pula restitusi, kompensasi, rehabilitasi, kepuasan, dan jaminan agar kejadian serupa tidak terulang. Ketiga, setiap negara harus mengumumkan melalui mekanisme publik maupun lembaga swasta baik di dalam maupun di luar negeri tentang tersedianya prosedur-prosedur pemulihan. Keempat, ketentuan-ketentuan pembatasan tidak boleh diterapkan selama masa dimana tidak ada penyelesaian efektif atas pelanggaran hak asasi manusia dan pelanggaran hukum humaniter. Kelima, setiap negara harus memungkinkan tersedianya secara cepat seluruh informasi yang berkenaan dengan persyaratan-persyaratan tuntutan pemulihan. Keenam, keputusan-keputusan menyangkut pemulihan atas korban pelanggaran hak asasi manusia dan pelanggaran hukum humaniter harus dilaksanakan melalui cara yang cermat dan cepat.

Ketiga kasus tersebut di atas semuanya telah sampai tahap pemeriksaan di pengadilan. Bahkan dalam kasus Yusman Telaumbanua telah dilakukan peninjauan kembali seiring dengan ditemukannya bukti baru atau novum setelah menjalani pidana penjara selama 5 (lima) tahun. Yusman dibebaskan setelah Mahkamah Agung mengeluarkan putusan yang membatalkan vonis mati PN Gunungsitoli sebelumnya terhadap Yusman pada Januari 2017. Dalam KUHAP dikenal adanya pra peradilan. Pra peradilan diartikan sebagai wewenang pengadilan negeri untuk memeriksa dan memutus menurut cara yang diatur dalam KUHAP, tentang:

a. Sah atau tidaknya suatu penangkapan dan atau penahanan atas permintaan tersangka atau keluarganya atau pihak lain atas kuasa tersangka;

b. Sah atau tidaknya penghentian penyidikan atau penghentian penuntutan atas permintaan demi tegaknya hukum dan keadilan.

Mengacu pada objek pra peradilan tersebut di atas, maka kekeliruan penerapan hukum tidak termasuk sebagai salah satu objek pra peradilan. Dengan demikian, korban unfair trial tidak dapat mengajukan ganti kerugian atau rehabilitasi.

\section{KESIMPULAN}

Masyarakat menilai bahwa peradilan pidana yang saat ini ada menunjukkan lemahnya kinerja aparat penegak hukum baik dalam tahap penyelidikan sampai dengan pemasyarakatan. Dalam beberapa kasus ditemukan adanya kekeliruan aparat penegak hukum dalam menerap-

\footnotetext{
${ }^{29}$ Arif Gosita, 1993, Masalah Korban Kejahatan Kumpulan Karangan, Akademika Pressindo, Jakarta, hal.63

${ }^{30}$ Ibid., hal.42

${ }^{31}$ Abdul Haris Semendawai, "Hak-Hak Korban Pelanggaran HAM Yang Berat (Tinjauan Hukum Internasional dan Nasional"),
} Jurnal Hukum No. 2 Vol. 16 April 2009, hal.257 
kan hukum khususnya dalam tahap penyelidikan dan penyidikan. Fakta hukum yang ditemukan oleh penyidik bukanlah suatu kebenaran materiil sebagaimana yang dikehendaki dalam fair trial. Kekeliruan yang dilakukan sejak dalam tahap penyelidikan dan penyidikan dijadikan dasar bagi jaksa penuntut umum untuk membuat dakwaan.

Selama ini, apabila terdapat kekeliruan dalam tugasnya sebagai penegak hukum, penyidik hanya melakukan pembebasan disertai permohonan maaf kepada korban. Kekeliruan penerapan hukum tidak termasuk sebagai salah satu objek pra peradilan, dalam berbagai peraturan perundang-undangan juga belum mengatur mengenai perlindungan hukum terhadap anak yang menjadi korban unfair trial.

\section{DAFTAR PUSTAKA}

\section{A. Buku}

Asshiddiqie, Jimly, 2007, Pokok-Pokok Hukum Tata Negara Indonesia Pasca Reformasi, Bhuana Ilmu Populer, Jakarta.

Atmasasmita, Romli, 1996, Sistem Peradilan Pidana Perspektif Eksistensialisme dan Abolisionisme, Bina Cipta, Bandung.

Fauzan dan Baharuddin Siagian, 2017, Kamus Hukum dan Yurisprudensi, Prena Media, Jakarta.

Gosita, Arif, 1993, Masalah Korban Kejahatan Kumpulan Karangan, Akademika Pressindo, Jakarta 2004, Masalah Perlindungan Anak, Bhuana Ilmu Populer, Jakarta.

Gultom, Maidin, 2014, Perlindungan Hukum Terhadap Anak dalam Sistem Peradilan Pidana Anak di Indonesia, Refika Aditama, Jakarta

Handoko, Ranu, 1996, Terminologi Hukum, Sinar Grafika, Jakarta.

Kaligis, O.C. 2006, Perlindungan Hukum atas Hak Asasi Tersangka Terdakwa dan Terpidana, Alumni, Bandung.

Reksodiputro, Mardjono, 2009, Sistem Peradilan Pidana Indonesia (Melihat Kepada Kejahatan Dan Penegakan Hukum Dalam Batas-Batas Toleransi, Fakultas Hukum Unversitas Indonesia, Jakarta

Soetedjo, Wagiati, 2011, Hukum Pidana Anak, Refika Aditama, Bandung.

Soekanto, Soerjono dan Sri Mamudji, 2012, Penelitian Hukum Normatif Suatu Tinjauan Singkat, Rajawali Pers, Jakarta.

\section{B. Peraturan Perundang-Undangan}

Pemerintah Indonesia, Undang-Undang Dasar 1945 Amandemen IV, Lembaran Negara Republik Indonesia No.14 Tahun 2006. Sekretariat Negara, Jakarta.

Pemerintah Indonesia, Undang-Undang No. 8 Tahun 1981 Tentang Kitab Undang-Undang Hukum Acara Pidana, Lembaran Negara Republik Indonesia No.76 Tahun 1981, Tambahan Lembaran Negara Republik Indonesia No.3209. Sekretariat Negara, Jakarta.

Pemerintah Indonesia, Keputusan Presiden No. 36 Tahun 1990 Tentang Ratifikasi Konvensi Hak Anak (Convention on the Rights of the Child) 
Pemerintah Indonesia, Undang-Undang No. 48 Tahun 2009 Tentang Kekuasaan Kehakiman, Lembaran Negara Republik Indonesia No. 157 Tahun 2009, Tambahan Lembaran Negara Republik Indonesia No. 5076. Sekretariat Negara, Jakarta.

Pemerintah Indonesia, Undang-Undang No. 11 Tahun 2011 Tentang Sistem Peradilan Pidana Anak, Lembaran Negara Republik Indonesia No.153 Tahun 2012, Tambahan Lembaran Negara Republik Indonesia No.5332. Sekretariat Negara, Jakarta.

Pemerintah Indonesia, Undang-Undang No. 35 Tahun 2014 Tentang Perubahan Atas UndangUndang Nomor 23 Tahun 2002 tentang Perlindungan Anak, Lembaran Negara Republik Indonesia No.297 Tahun 2014, Tambahan Lembaran Negara Republik Indonesia No.5606. Sekretariat Negara, Jakarta.

\section{Jurnal atau Artikel}

Abdul Haris Semendawai, "Hak-Hak Korban Pelanggaran HAM Yang Berat Tinjauan Hukum Internasional dan Nasional”, Jurnal Hukum Vol. 16 No. 2, April 2009.

Agus Raharjo dan Angkasa, "Profesionalisme Polisi dalam Penegakan Hukum”, Jurnal Dinamika Hukum, Vol. 11 No.3, September 2011

\section{Website}

CNN. Survei LSI Kepercayaan Publik Terhadap POLRI Paling Merosot. https://www.cnnindonesia. com/nasional/20191113181236-20-448092/survei-lsi-kepercayaan-publik-terhadappolri-paling-merosot diakses pada tanggal 04 Juni 2020.

Detik. Mencuri 3 Buah Kakao Nenek Minah Dihukum 1 Bulan 15 Hari. https://news.detik. com/berita/d-1244955/mencuri-3-buah-kakao-nenek-minah-dihukum-1-bulan-15-hari diakses pada tanggal 07 Juni 2020.

Kompas, Kisah Yusman Mantan Terpidana Mati Dibawah Umur Yang Mengaku Kena Rekayasa. https://nasional.kompas.com/read/2017/08/23/12060601/kisahyusmanmantanterpidanamatidibawahumuryangmengakukenarekayasa?page=all diakses pada tanggal $08 \mathrm{Juni}$ 2020.

Makassar Terkini. Tim Advokat Untuk Orang Asli Papua Terdakwa IH Dibebaskan Dari Tahanan. https://makassar.terkini.id/tim-advokat-untuk-orang-asli-papua-terdakwa-ihdibebaskan-dari-tahanan/ diakses pada tanggal 07 Juni 2020

Tribun. Begini Kisah Mispo Gwijangge Bocah 14 Tahun Yang Dituduh Bunuh 17 Karyawan PT Istaka Karya Di Ndug. https://tribun-arafura.com/2020/02/04/begini-kisah-mispogwijangge-bocah-14-tahun-yang-dituduh-bunuh-17-karyawan-pt-istaka-karya-di-nduga/ diakses pada tanggal 03 Juni 2020.

Voa Indonesia, Terdakwa Hukuman Mati Kasus Istaka Karya Papua Diduga Masih Anak. https:// www.voaindonesia.com/a/terdakwa-hukuman-mati-kasus-istaka-karya-papua-didugamasih-anak/5306384.html diakses pada tanggal 08 Juni 2020. 
Dini Eka Wati | Penerapan Fair Trial dalam Menentukan Usia Anak, Tinjauan Terhadap Sistem Peradilan. 